\title{
Modelling the Nexus in Foreign Capital Flows and Environmental Degradation: Fresh Evidence From Global Data
}

Muhammad Azam Khan

Abdul Wali Khan University Mardan

Ali Raza ( $\square$ aliraza@uoh.edu.pk)

The University of Haripur https://orcid.org/0000-0003-1246-0162

\section{Research Article}

Keywords: $\mathrm{CO} 2$ emission, FDI inflows, pollution haven hypothesis, panel data

Posted Date: April 30th, 2021

DOI: https://doi.org/10.21203/rs.3.rs-379777/v1

License: (c) (1) This work is licensed under a Creative Commons Attribution 4.0 International License.

Read Full License 


\title{
Modelling the nexus in foreign capital flows and environmental degradation: Fresh evidence from Global data
}

\begin{abstract}
Environmental degradation, if not controlled, is one of the dangers faced by humankind. Achieving sustainable development is impossible without improving environmental quality. The 17 United Nations Sustainable Development Goals are intended to lead to improvements toward a sustainable future. We explore empirically the interrelationship between foreign capital flows/foreign direct investment (FDI) and environmental quality measured by carbon dioxide $\left(\mathrm{CO}_{2}\right)$ emissions for a panel of 125 countries in 1990-2018 by revisiting the pollution haven hypothesis $(\mathrm{PHH})$. This study employed a system generalised method of moments (GMM). The GMM estimates show that FDI has a significantly positive link with $\mathrm{CO}_{2}$ in Asia and Africa, but the links between these two variables are insignificant in the Latin American, Caribbean and European regions. In the cases of full sample and developing countries, a significantly positive relationship is found between FDI and $\mathrm{CO}_{2}$. In the case of income-based samples, results reveal that FDI is the cause of environmental degradation in low-income, lower middle-income and upper middle-income countries. We contribute to the available literature by re-examining the PHH and presenting the impact of inward FDI on $\mathrm{CO}_{2}$, where the results demonstrate that the $\mathrm{PHH}$ is valid in full-sample, regional and income-wise countries. These findings suggest that developing countries should adopt environmentally friendly policies to attract foreign investors by setting strict regulations on environmental pollution control to achieve sustainable development goals (SDGs).
\end{abstract}

Keywords: $\mathrm{CO}_{2}$ emission; FDI inflows; pollution haven hypothesis; panel data 


\section{Introduction}

The efficient utilisation of foreign capital flows particularly foreign direct investment (FDI) in economic growth and development cannot be overlooked. Most countries attract FDI by promoting economic growth while violating environmental policies in some cases. Developing countries focus on attracting FDI, thereby increasing economic activities in a host country while ignoring its adverse effects such as pollution, which exacerbates global warming and climate change. Although FDI contributes to an increase in capital stock, technological innovations, employment opportunities and per capita income (Destek and Okumus 2019), it has adverse effects on the natural environment (Shahbaz et al. 2015). According to Intergovernmental Panel on Climate Change (IPCC 2019) study, global warming above preindustrial levels of round 1.5 ${ }^{\circ} \mathrm{C}$ is a climate change issue. Most environmentalists agree that the world mean temperature should not increase by more than $2{ }^{\circ} \mathrm{C}$ (Edenhofer et al. 2013). $\mathrm{CO}_{2}$ emissions are primary source of environmental pollution and global warming, thereby causing countries to pay attention to the side effects of $\mathrm{CO}_{2}$ emissions. Developed countries have paid close attention to this problem and tightened their environmental policies, but the problem lies on the side of developing countries and emerging economies. Developing countries have to implement friendly, clean and green environmental pollution policies to obtain the benefits of economic growth (Azam and Ozturk 2020).

The literature reveals that pollution haven hypothesis (PHH) has been widely discussed and applied by many researchers. The PHH posits that nations attract FDI only by focusing on economic growth coupled with weak environmental protection policies. The cost of pollution is higher in developing countries than in developed countries (Mani and Wheeler 1998). The problem with developing countries is their weak environmental protection policies, which have caused developed nations to shift their industries to developing countries (Cole 2004). Developing countries attract FDI and this FDI mostly comes in the form of industries and manufacturing sectors. Investment and trade in developing countries are the reasons for high $\mathrm{CO}_{2}$ emissions (Solarin et al. 2017). On the other hand, developed countries have regulated their industries according to adequate environmental policies, thereby protecting nature and the environment from high $\mathrm{CO}_{2}$ emissions. Countries that have adopted adequate protective environmental policies on pollution are less attractive to foreign investors (Cole and Fredriksson 2009; Neequaye and Oladi 2015).

Due to globalisation, multinational firms consider developing countries as safe havens where they invest and therefore can pollute the environment (He 2006). Along with relaxed and less protective environmental policies, low labour costs and abundant natural resources in developing countries have attracted investments from multinational firms. FDI is considered as the best recourse in financing large investment projects and modern technology transfer (Destek and Okumus 2019). Although incoming FDI contributes toward the economic growth of developing countries, these countries have relaxed environmental policies for attracting FDI, thereby having an adverse effect on the environment (Miniesy and Tarek 2019). Based on relaxed environmental policies, the sustainability of reduced air pollution is a serious concern. Climate change also worsens due to reduced attention to the air pollution mainly caused by $\mathrm{CO}_{2}$ emissions. Both developing and developed nations face the negative consequences of climate change, which brings severe weather disturbance around the world (United Nations 2019). The United Nations has set Sustainable Development Goals for its member countries to overcome not only environmental issues but also economic problems. 
In their study, Destek and Okumus (2019) stated that in recent years, developing countries have faced financial problems that they addressed through FDI. FDI not only helps to introduce high technology with the latest features to solve environmental pollution problems but also helps to spur economic growth. The introduction of FDI to host countries with environmental and economic consequences remains a subject of debate. The foreign investment is usually due to abundant natural resources and the availability of cheap labour in a host country. The problem with such foreign investment is that multinational companies from developed countries take advantage of loose environmental protection regulations, thereby spreading pollution. The developing countries take advantage of industry hubs while investors enjoy low-cost production, thereby encouraging more polluting industries to migrate to developing countries (Nunneenkamp 2001). Pollution halo hypothesis (PHH) (Mert and Caglar 2020) states that investment in host counties is based on modern production technologies that do not make the environment dirty.

104

105

106

107

108

109

110

111

112

113

114

115

116

117

118

119

120

121

122

123

124

125

126

127

128

129

130

131

132

133

134

135

136

137 Thus, based on the PHH, this study aims to determine the occurrence of increasing or decreasing combinations of FDI and environmental pollution.

The rationale behind this analysis is that sustainable development is indispensable and impossible without maintaining a clean and green environment. Several factors are responsible for environmental degradation, where one of the factors is FDI inflows to the host countries. Thus, the broad objective of this study is to examine the causal association between FDI inflows and environmental quality based on $\mathrm{CO}_{2}$ emissions for a panel of 125 countries ${ }^{1}$ over the period 1990-2018. To the best of the author's knowledge, this study is different from other studies for three reasons. First, we conduct a comparative analysis of four regions, i.e., Africa, Asia, Europe, and Latin America and Caribbean, whereas other studies have worked only on a single regional sample. Second, we evaluate the samples of low, lower-middle, upper-middle and high income/developed countries and also focus on the comparison of the samples of developing countries, developed countries and full samples, whereas other studies worked on examining the samples of either developing or developed countries. Third, we also examine the Granger causality for all sample countries. The empirical outcomes of this study are expected to guide the management authorities in the developing world when formulating public policies to accomplish sustainable development.

This study is structured as follows: Section 2 reviews prior studies. Section 3 presents data and variables, model specification and empirical methodology. Section 4 provides empirical results and discussion. Finally, section 5 concludes the study.

\section{Review of Literature}

Numerous studies are available on the relationship between FDI inflows and $\mathrm{CO}_{2}$ emissions under PHH for different samples of developed, developing, regional, income-wise and mixture of countries. For example, Pao and Tsai (2011) employed the Granger causality test to characterise the relationship between FDI, GDP, energy consumption and $\mathrm{CO}_{2}$ emissions for Brazil, Russia, India and China countries during the period 1980-2007 and found that the hypotheses of PHH are valid. The study of Al-Mulali (2012) investigated the relationship between FDI, GDP, trade, consumption and $\mathrm{CO}_{2}$ emissions for 12 Middle East countries. The study claimed that FDI, GDP, trade and energy consumption increases $\mathrm{CO}_{2}$ emissions from of 1990-2009. Al-Mulali and Tang (2013) found that FDI has a negative relationship with $\mathrm{CO}_{2}$ emissions, thereby confirming the PHH in Gulf countries in 1980-2009. Aliyu and Ismail (2015) found that FDI and energy consumption have positive and significant impacts on $\mathrm{CO}_{2}$ emissions

\footnotetext{
${ }^{1}$ Refer to Appendix Table A1 for list of countries.
} 
in 19 African developing countries. Further findings also revealed the evidence of the PHH validity and suggested strict environmental policies to keep pollution in check. Shahbaz et al. (2015) observed that PHH is valid in selected developing and developed countries based on income from 1975-2012. The Granger causality results show a bi-directional causality between FDI and $\mathrm{CO}_{2}$ emissions and also between energy consumption and $\mathrm{CO}_{2}$ emissions. Sapkota and Bastola (2017) proposed attractive policies focused on clean and energy-efficient foreign investment that could further improve environmental health and economic growth in 14 Latin American countries over 1980-2010. The findings of the study revealed the validity of PHH and environmental Kuznets curve (EKC) not only for the full sample but also for high- and lowincome countries.

Baek and Choi (2017) found that FDI increases $\mathrm{CO}_{2}$ emissions and confirmed the validity of PHH in 17 Latin American economies for the time period of 1971-2011. The research divided the sample into low-, middle- and high-income countries but the positive impact of FDI on $\mathrm{CO}_{2}$ emissions was only confirmed in high-income countries. Solarin and Al-Mulali (2018) observed that inward FDI and environmental degradation have an insignificant relationship in a panel of 20 countries in 1982-2013. To et al. (2019) concluded that in 25 emerging markets in Asia over 1980-2016, first stage FDI increases emissions and then in the second stage, the FDI causes $\mathrm{CO}_{2}$ emissions to decrease. Further findings reveal that oil consumption and per-capita income also have adverse effects on $\mathrm{CO}_{2}$ emissions. However, Fakher (2019) studied developing countries using Bayesian estimator for 1996-2016 and claimed the validity of PHH. Li et al. (2019) found that in case of full samples, FDI has no significant impact on $\mathrm{CO}_{2}$ emissions in 40 developed and developing countries in 1990-2014. In the case of developed countries, results show positive influence of FDI, whereas in the case of developing countries, FDI has a statistically insignificant effect on $\mathrm{CO}_{2}$ emissions. Guzel and Okumus (2020) analysed the validity of PHH in five Southeast Asian countries during 1981-2014 and found that an increase in FDI caused environmental degradation. The authors suggest that $\mathrm{CO}_{2}$ emissions intensify with an increase in energy consumption and that the EKC hypothesis is also valid. Further findings suggest that a Ushaped curve exists between economic growth and $\mathrm{CO}_{2}$ emissions.

Sinha et al. (2020) observed that in the long run, financial development is considered as a cause of $\mathrm{CO}_{2}$ emissions increase in high-income countries, whereas an opposite case is observed in non-high-income countries in 1980-2013. In high income nations, trade does not impact $\mathrm{CO}_{2}$ emissions, whereas it causes an increase of $\mathrm{CO}_{2}$ emissions in non-high-income countries. Erdogan et al. (2020) found that EKC is invalid for a panel of 25 countries from the Organisation for Economic Co-operation and Development in 1990-2014. The study also observed that oil prices and rising renewable energy consumption decreases $\mathrm{CO}_{2}$ emissions while non-renewable energy consumption spur $\mathrm{CO}_{2}$ emissions. Results indicate no significant relationship between trade openness and $\mathrm{CO}_{2}$ emissions. In a similar vein, Azam and Ozturk (2020) assessed the effect of inward FDI on $\mathrm{CO}_{2}$ emissions on a sampled data of 17 Asian countries for 1980-2014 using FMOLS technique and found that inward FDI causes an increase in $\mathrm{CO}_{2}$ emissions. Further findings of the study revealed that economic growth and trade openness also cause environmental pollution due to $\mathrm{CO}_{2}$ emissions. A summary of other related empirical studies is presented in Table 1.

\section{[Table 1]}

\section{Data and empirical methodology Data and variables}


Data used in this study are obtained from the World Development Indicator (World Bank, 2020), and $\mathrm{CO}_{2}$ Emissions, Global Carbon Atlas (2020). Descriptions of variables are given in Table 2.

\section{Empirical model}

\section{[Table 2]}

To achieve the research objective, we use $\mathrm{CO}_{2}$ emissions as response variables that are also used by Selden and Song (1994) to measure the influence of income (GDP) and population on $\mathrm{CO}_{2}$ emissions. Moomaw and Unruh ((1997) also explained the impact of $\mathrm{CO}_{2}$ as a response variable using the panel data of 16 countries and supports the validity of EKC. Thus, we apply the following multivariate regression model, which was also used by prior researchers including Behera and Dash (2017), Albulescu et al. (2019), Miniesy and Tarek (2019), Azam and Ozturk (2020) and Rafique et al. (2020) and can be written symbolically as follows:

$$
C O_{2 \mathrm{it}}=\alpha_{0}+\alpha_{1} \mathrm{X}_{i t}+\alpha_{2} \mathrm{Z}_{i t}+\gamma_{t}+\eta_{i}+\mu_{i t}
$$

where $\mathrm{CO}_{2 \mathrm{it}}$ represents the emissions of each country $i$ in time $t, \mathrm{X}_{i t}$ is a target variable, $\mathrm{Z}_{i t}$ is a set of controlled variables, $\gamma_{t}$ is unobserved time-period effect, $\eta_{i}$ is unobserved country effect and $\mu_{i t}$ varies across countries and time.

Rearranging Eq. (1), we obtain

$$
C O_{2 \mathrm{it}}=\alpha_{1 i}+\alpha_{2} F D I_{i t}+\alpha_{3} G D P+\alpha_{4} \text { Pop }_{i t}+\alpha_{5} \text { energy }_{i t}+\alpha_{6} \text { export }_{i t}+\alpha_{7} \text { industry }_{i t}+\varepsilon_{i t}
$$

In the extant literature, the random-effects model is also known by an error component model. In Eq. (2), the country's individual intercept value can be written as

where $\alpha_{i t}=\alpha_{1}+v_{i}$.

Replacing Eq. (2) leads to the following equation:

$$
C O_{2 \mathrm{it}}=\alpha_{1}+\alpha_{2} F D I_{i t}+\alpha_{3} G D P+\alpha_{4} \text { Pop }_{i t}+\alpha_{5} \text { energy }_{i t}+\alpha_{6} \text { export }_{i t}+\alpha_{7} \text { industry }_{i t}+\varepsilon_{i t}+v_{i} \text {, }
$$

whereas $\sigma_{i t}=\varepsilon_{i t}+v_{i}$ is replaced in Eq. (3). $\sigma_{i t}$ is an error term composed of two effects, i.e., $\varepsilon_{i t}$, which is an individual specific effect, while $v_{i}$ is a time series and error component effect. Thus, Eq. (3) finally becomes

$$
C O_{2 \mathrm{it}}=\alpha_{1}+\alpha_{2} F D I_{i t}+\alpha_{3} G D P+\alpha_{4} \text { Pop }_{i t}+\alpha_{5} \text { energy }_{i t}+\alpha_{6} \text { export }_{i t}+\alpha_{7} \text { industry }_{i t}+\sigma_{i t} \text {. }
$$

Eq. (4) is the final equation for fixed-effects (FE) analysis, whereas Eq. (2) is used for the analysis of the generalised method of moment (GMM) approach.

\section{Estimation strategy}

Before empirical investigation of long-term data, we have to test the stationarity properties of data. We employed panel unit-root test proposed by Im, Pesaran and Shin (IPS) (2003) to check stationarity. The traditional panel data analysis techniques, namely, FE and random-effects (RE) 
are commonly used in the literature ${ }^{2}$. We use the RE estimator as suggested by the Hausman test (1978). In addition, the GMM estimator is employed, thereby reducing the risk of biased results because the endogeneity problem is controlled for all explanatory variables. Blundell and Bond (1998) propose system GMM, which encounters the endogeneity problem by introducing instrumental variables within the model. The method system GMM estimator incorporates a normal set of equations in first differences with the correct lagged levels as instruments, with an additional equation in levels with the correct lagged first differences as instruments. The validity of instruments, which offer an over-identifying collection of restrictions has been confirmed by Hansen test and ensures that the collection of instruments is correct in all situations. Arellano and Bond (1991) and Arellano and Bover (1995) suggests the AR (2) test, which is also used to confirm the hypothesis of the absence of serial correlation. The normal coefficient errors are resilient against heteroscedasticity. Granger (1969) developed a model of the causality between two variables for time-series data. A causality problem remained in the panel data set and the latest development to solve that problem was presented by Dumitrescu and Hurlin (2012). The study used this method to identify Granger causality and the results were analysed. Analytical Framework is shown in Figure 1.

\section{[Figure 1]}

\section{Result and Discussions}

We employed the IPS panel-unit root test by Im et al. (2003) for stationarity checking of the series. The IPS test worked best in the balanced panel dataset and is also suitable for the dynamic heterogeneous panel results because it enables heterogeneity across countries such as individual effects and specific patterns of residual serial correlations. The second advantage is that the IPS test controls the cross-sectional dependence of the errors. The third advantage is that other tests such as those by Levin, Lin and Chu (LLC) (2002) and Quah (1994) is based on pooled regressions, while the IPS test considers a combination of various independent tests and does not pool data as the LLC and Q tests do.

IPS panel unit root test analyses (region based sample countries) are given in Table 3, and IPS panel unit root test analysis (Developed, Developing, Full sample countries, and Income based sample countries are given in Table 4. The panel unit-root test is a prerequisite for any of the panel datasets prior to empirical investigation of the data. The most relevant test used in this analysis is the IPS test. The stationarity of all variables is first checked only with the constant, and then both at level and first difference with the constant and trend terms. From the unit root test results, the maximum of the variables was considered stationary for both the constant and constant and trend term at the first difference.

\section{[Table 3]}

[Table 4]

We initially employed the traditional panel data estimation techniques encpmasses FE and RE estimator. To ensure robustness of findings, we employed the FE and RE techniques, but the Hausman test is preferred in using the RE over the FE estimator. Random-effects and GMM estimates on regional wise analysis; developing, developed and full sample analysis; and income wise analysis are given in Table 5, Table 6, and Table 7 respectively. Findings on the countries

\footnotetext{
${ }^{2}$ Refer to Azam and Ahmed (2015) and Azam (2019) for traditional panel data analysis technique.
} 
sampled in Asia and Africa show that FDI raises environmental emissions and have a positive effect on $\mathrm{CO}_{2}$ emissions. The studies by Miniesy and Tarek (2019) and Azam and Ozturk (2020) support this outcome. Controlled variables GDP population and energy consumption in export and industry also have a positive and significant impact on $\mathrm{CO}_{2}$ emissions in Asia and Africa. However, the latter two variables are negative and insignificant in sampled African countries. In the case of the countries sampled in Latin America and the Caribbean, FDI has an insignificant relationship with $\mathrm{CO}_{2}$ emissions and does not help increase pollution. These results are in accordance with the findings of Albulescu et al. (2019), and the authors of the present study report the same results. Similar to Asia and Africa, the outcomes for developing and complete sample countries is the same, with FDI responsible for increasing emissions. Omri et al. (2014) found the same results for countries in Europe and Central Asia, Latin America and the Caribbean, Middle East and North Africa, and sub-Saharan Africa. The study evaluated that FDI and trade openness increases emission of $\mathrm{CO}_{2}$ emissions, thereby polluting the atmosphere. In the findings on developed sampled countries, FDI is negligible, similar to the findings by Sinha et al. (2020). The author believes that the cause of rising $\mathrm{CO}_{2}$ emissions is financial growth.

In the case of income-based sample results, in low-income, lower middle-income and upper middle-income developing countries, FDI contributes toward promoting environmental pollution. Neequaye and Oladi (2015) also found similar results. The controlled variables, namely, energy usage and GDP, have a strong impact in low-income and lower middle-income countries, but population has a negative and statistically significant relationship with $\mathrm{CO}_{2}$ emissions. A negative and statistically insignificant relationship exists between exports and $\mathrm{CO}_{2}$ emissions and industrial value added. . Energy consumption, GDP, exports and population are significant and positive in the sample of upper middle-income countries, but the latter is negatively related to $\mathrm{CO}_{2}$ emissions.

Results also show that in the sample Asian and African countries, FDI has a positive and significant effect on $\mathrm{CO}_{2}$ emissions. In the Latin American and Caribbean countries, FDI plays an insignificant role in environmental pollution. In the case of European sampled countries, FDI has no role in increasing pollution. Amongst all sampled countries based on income, FDI is responsible for air pollution.

[Table 5]

[Table 6]

[Table 7]

The Dumitrescu and Hurlin (DH) (2012) Granger causality test was employed to determine the direction of causality and results are given in Table 8 . The null hypothesis is that in the results of this analysis, $\mathrm{CO}_{2}$ emissions do not cause FDI that is rejected with a low p-value and vice versa. The test was used in full-sample, income-wise and region-wise countries and provides $\mathrm{PHH}$ validity in all of the sampled categories. These findings are consistent with those of Pao and Tsai (2011), Vinh (2015), Tang and Tan (2015) and Shahbaz et al. (2015). These studies also believed that $\mathrm{CO}_{2}$ emissions and FDI are bi-causal. The results of the $\mathrm{DH}$ test show that all variables have bidirectional causality relations with one another at $5 \%$ significance level in regional, income and developing and developed sample cases.

\section{Summary and Conclusion}

[Table 8] 
This study aims to empirically explore the validity of the $\mathrm{PHH}$ using inward FDI and $\mathrm{CO}_{2}$ emissions for a panel of 125 countries for 1990-2018. Panel unit root test, namely IPS and the method of system GMM, is used as an analytical technique. The Dumitrescu and Hurlin (DH) Granger causality test is implemented to determine the direction of causality. The results show that control variables GDP, population, export, energy and industry also affect $\mathrm{CO}_{2}$ emissions but population has a positive and negative effect in Africa and Asia, respectively. Exports and industry in Asia are optimistic, but negative in Africa. In Latin America and Caribbean and European countries, respectively, FDI has minimal positive and negative effects. Similarly, population, industry and energy have a huge influence in both regions. This study concludes that Asia and Africa have been badly affected by FDI due to the absence of strict environmental policies. However, strict environmental regulatory authorities in Latin American and Caribbean and European countries have imposed strict pollution control rules on industrial estates, and thus, these two regions are protected. Another possible reason is the existence of new technology deployed in the pollution-protecting industries.

Incoming FDI, GDP, population and energy have positive and statistically significant effects on $\mathrm{CO}_{2}$ emissions in the case of income-based research except for a population that has a negative link with $\mathrm{CO}_{2}$ emissions. The explanation for FDI is that these income-based countries have an abundance of natural resources and draw a large number of foreign investors who do not comply with the regulations on environmental pollution. Export has negative effect on $\mathrm{CO}_{2}$ emissions in low-income and lower middle-income countries, whereas industry has a negative but insignificant impact on $\mathrm{CO}_{2}$ emissions only in low-income countries. Similarly, FDI also plays a substantially positive role in intensifying the environmental pollution in the sample study of developing countries because these developing countries are at the starting point of development and are expanding their economies. Control variables GDP, population, energy, export and industry all have a significantly positive effect on $\mathrm{CO}_{2}$ emissions. The case of developed countries then varies from that of developing countries, where FDI has a statistically marginal effect on contamination of the atmosphere. This condition means that all these conditions are possible in developed countries by using high-technology machinery and adopting strict policies on environmental pollution. Environmentally friendly policies need to be strictly executed to achieve sustainable development and thereby promote social welfare.

\section{AUTHOR DECLARATION}

\section{Ethical Approval and Consent to Participate}

The authors declare that they have no conflict of interest.

\section{Consent to Publish}

We all two authors agree to publish our research work with ESPR.

\section{Conflict of interest statement}

There is no any issue of conflict of interest in our article.

\section{Funding}

No funding was received from any funding agencies. 


\section{Data Availability Statement}

The data used in this study are openly available, and can be provided upon request. The data have been taken from these sources: World Development Indicators (2020), the World Bank publication. http://data.worldbank.org/country; and CO2 Emissions, Global Carbon Atlas (2020). Retrieved from http://www.globalcarbonatlas.org/en/CO2-emissions

\section{$\underline{\text { Authors contribution/credit author statement }}$}

Muhammad Azam (First author): Conceptualization, Supervision, Reviewing and Editing Ali Raza ( $2^{\text {nd }}$ author): Data curation, and writing- draft preparation

\section{References}

Albulescu C T, Tiwari A K, Yoon S M, Kang S H (2019) FDI, income and environmental pollution in Latin America: Replication and extension using panel quantiles regression analysis. Energy Economics 104504. https://doi.org/10.1016/j.eneco.2019.104504

Aliyu A J, Ismail N W (2015) Foreign direct investment and pollution haven: does energy consumption matter in African countries. International Journal of Economics and Management 9(1):21-23.

Al-mulali U, (2012) Factors affecting CO2 emission in the Middle East: A panel data analysis. Energy 44(1):564-569.

Al-Mulali U, Tang C F (2013) Investigating the validity of pollution haven hypothesis in the gulf cooperation council (GCC) countries. Energy Policy 60:813-819.

Arellano M, Bond S (1991) Some tests of specification for panel data: Monte Carlo evidence and an application to employment equations. The Review of Economic Studies 58(2):277-297.

Arellano M, Bover O (1995) Another look at the instrumental variable estimation of errorcomponents models. Journal of Econometrics 68(1):29-51.

Azam M K, Ozturk I, (2020) Examining foreign direct investment and environmental pollution linkage in Asia. Environmental Science and Pollution Research 27 (7):7244-7255.

Azam M, (2019) Inequality and economic growth in Asia and the Pacific region. African and Asian Studies 18 (3):288-314.

Azam M, Ahmed M A (2015) Role of human capital and foreign direct investment in promoting economic growth: Evidence from Commonwealth of Independent States. International Journal of Social Economics 42(2):89-111

Azam M, Khan A Q (2016) Testing the environmental Kuznets curve hypothesis: a comparative empirical study for low, lower middle, upper middle and high income countries. Renewable and Sustainable Energy Reviews 63:556-567

Baek J, Choi Y J (2017) Does foreign direct investment harm the environment in developing countries. Dynamic panel analysis of Latin American countries. Economies 5(4):39, https://doi.org/10.3390/economies5040039

Behera S R, Dash D P (2017) The effect of urbanization, energy consumption, and foreign direct investment on the carbon dioxide emission in the SSEA (South and Southeast Asian) region. Renewable and Sustainable Energy Reviews 70:96-106.

Blundell R, Bond S (1998) Initial conditions and moment restrictions in dynamic panel data models. Journal of Econometrics 87(1):115-143. 
Change I C (2019) Land: An IPCC Special Report on climate change, desertification, land degradation, sustainable land management, food security, and greenhouse gas fluxes in terrestrial ecosystems. 2019. In The approved Summary for Policymakers (SPM) was presented at a press conference on (Vol. 8).

Cole M A (2004) Trade, the pollution haven hypothesis and the environmental Kuznets curve: examining the linkages. Ecological Economics 48(1):71-81.

Cole M A, Fredriksson P G (2009) Institutionalized pollution havens. Ecological Economics 68(4):1239-1256.

$\mathrm{CO} 2$ Emissions, Global Carbon Atlas, (2020) Retrieved from http://www.globalcarbonatlas.org/en/CO2-emissions

Destek M A, Okumus I (2019) Does pollution haven hypothesis hold in newly industrialized countries. Evidence from ecological footprint. Environmental Science and Pollution Research 26:23689-2369.

Dumitrescu E I, Hurlin C (2012) Testing for Granger non-causality in heterogeneous panels. Economic Modelling 29(4):1450-1460.

Edenhofer O, Flachsland C, Jakob M, Lessmann K (2013) The Atmosphere as a Global Commons Challenges for International Cooperation and Governance. MCC working paper 1-2013, and Discussion Paper 2013-58, Harvard Project on Climate Agreements, Belfer Center for Science and International Affairs, Harvard Kennedy School.

Erdogan S, Okumus I, Guzel A E (2020) Revisiting the Environmental Kuznets Curve hypothesis in OECD countries: the role of renewable, non-renewable energy, and oil prices. Environmental Science and Pollution Research 27:23655-23663

Fakher H A (2019) Investigating the determinant factors of environmental quality (based on ecological carbon footprint index). Environmental Science and Pollution Research 26(10):10276-10291.

Granger C W (1969) Investigating causal relations by econometric models and cross-spectral methods. Econometrica 37(3):424-438.

Guzel A E, Okumus İ (2020) Revisiting the pollution haven hypothesis in ASEAN-5 countries: new insights from panel data analysis. Environmental Science and Pollution Research 1-11.

Hausman J A (1978) Specification tests in econometrics. Econometrica: Journal of the Econometric Society 1251-1271.

He J (2006) Pollution haven hypothesis and environmental impacts of foreign direct investment: The case of industrial emission of sulfur dioxide (SO2) in Chinese provinces. Ecological Economics 60(1):228-245

Im K S, Pesaran M H, Shin Y (2003) Testing for unit roots in heterogeneous panels. Journal of Econometrics 115(1):53-74.

Khan M A, Ozturk I (2020) Examining foreign direct investment and environmental pollution linkage in Asia. Environmental Science and Pollution Research 27(7):7244-7255.

Levin A, Lin C F, Chu C S J (2002) Unit root tests in panel data: asymptotic and finite-sample properties. Journal of Econometrics 108(1):1-24.

Mani M, Wheeler D (1998) In search of pollution havens. Dirty industry in the world economy, 1960 to 1995. The Journal of Environment and Development 7(3):215-247.

Mert M, Caglar A E (2020) Testing pollution haven and pollution halo hypotheses for Turkey: a new perspective. Environmental Science and Pollution Research. https://doi.org/10.1007/s11356-020-09469-7 
Miniesy R S, Tarek M (2019) Is there evidence of PHH in developing Asia. Journal of Chinese Economic and Foreign Trade Studies 12(1):20-39.

Moomaw W R, Unruh G C (1997) Are environmental Kuznets curves misleading us. The case of $\mathrm{CO}_{2}$ emissions. Environment and Development Economics 2(4):451-463.

Neequaye N A, Oladi R (2015) Environment, growth, and FDI revisited. International Review of Economics and Finance 39:47-56.

Nunnenkamp P (2001) Foreign direct investment in developing countries: What policymakers should not do and what economists don't know (No. 380). Kieler Diskussionsbeiträge.

Omri A, Nguyen D K, Rault C (2014) Causal interactions between CO2 emissions, FDI, and economic growth: Evidence from dynamic simultaneous-equation models. Economic Modelling 42:382-389.

Pao H T, Tsai C M (2011) Multivariate Granger causality between $\mathrm{CO}_{2}$ emission, energy consumption, FDI and GDP: evidence from a panel of BRIC countries. Energy 36:685-693.

Quah D (1994) Exploiting cross-section variation for unit root inference in dynamic data. Economics letters 44(1-2):9-19.

Rafique M Z, Li Y, Larik A R, Monaheng M P (2020) The effects of FDI, technological innovation, and financial development on $\mathrm{CO} 2$ emissions: evidence from the BRICS countries. Environmental Science and Pollution Research 1-15. https://doi: 10.1007/s11356-020-08715-2.

Sapkota P, Bastola U (2017) Foreign direct investment, income, and environmental pollution in developing countries: Panel data analysis of Latin America. Energy Economics 64:206212.

Selden T M, Song D (1994) Environmental quality and development: is there a Kuznets curve for air pollution emissions. Journal of Environmental Economics and Management 27(2):147-162.

Shahbaz M, Nasreen S, Abbas F, Anis O (2015) Does foreign direct investment impede environmental quality in high, middle and low-income countries. Energy Economics 51: 275-287.

Sinha A, Kumar A, Gopalakrishnan B N (2020) Environmental Kuznets Curve and Pollution Haven Hypothesis. MPRA Paper No. 98930.

Solarin S A, Al-Mulali U (2018) Influence of foreign direct investment on indicators of environmental degradation. Environmental Science and Pollution Research 25(25):2484524859.

Solarin S A, Al-Mulali U, Musah I, Ozturk I (2017) Investigating the pollution haven hypothesis in Ghana: an empirical investigation. Energy 124:706-719.

Tamazian A, Rao B B (2010) Do economic, financial and institutional developments matter for environmental degradation. Evidence from transitional economies. Energy Economics 32(1):137-145.

Tang C F, Tan B W (2015) The impact of energy consumption, income and foreign direct investment on carbon dioxide emissions in Vietnam. Energy 79:447-454.

To A H, Ha D T T, Nguyen H M, Vo D H (2019) The impact of foreign direct investment on environment degradation: Evidence from emerging markets in Asia. International Journal of Environmental Research and Public Health 16(9):1636. https://doi.org/10.3390/ijerph16091636.

United Nations (2019) The Sustainable Development Goals Report 2019. 
Vinh C T H (2015) The two-way linkage between foreign direct investment and environment in Vietnam from sectoral perspectives. Working paper, Foreign Trade University, Vietnam.

498 World Development Indicators (WDI) (2020). World Bank World Indicators Database.

Zhu H, Duan L, Guo Y, Yu K (2016) The effects of FDI, economic growth and energy consumption on carbon emissions in ASEAN-5. Evidence from panel quantile regression. Economic Modelling 58:237-248.

502

503

Appendix

504 Table A 1. List of countries

\begin{tabular}{|c|c|}
\hline Asia (37) & $\begin{array}{l}\text { Azerbaijan, Bahrain, Bangladesh, Brunei Darussalam, Cambodia, China, Georgia } \\
\text { Hong Kong, India, Indonesia, Iran, Iraq, Israel, Japan, Jordan, Kazakhstan, Korea, } \\
\text { Rep., Kyrgyz Republic, Lebanon, Malaysia, Mongolia, Myanmar, Nepal, Oman, } \\
\text { Pakistan, the Philippines, Saudi Arabia, Singapore, Sri Lanka, Syria, Tajikistan, } \\
\text { Thailand, Turkey, Turkmenistan, and United Arab Emirates }\end{array}$ \\
\hline Afri & $\begin{array}{l}\text { Algeria, Angola, Benin, Botswana, Cameroon, Congo, Dem. Rep., Congo, Rep., } \\
\text { Cote d'Ivoire, Egypt, Eritrea, Gabon, Ghana, Kenya, Mauritius, Morocco, } \\
\text { Mozambique, Namibia, Nigeria, Senegal, South Africa, Sudan, Tanzania, Togo, } \\
\text { Tunisia, Zambia, and Zimbabwe }\end{array}$ \\
\hline Eurc & $\begin{array}{l}\text { Albania, Austria, Belarus, Belgium, Bosnia and Herzegovina, Bulgaria, Croatia, } \\
\text { Cyprus, Czech Republic, Denmark, Estonia, Finland, France, Germany, Greece, } \\
\text { Hungary, Iceland, Ireland, Italy, Latvia, Lithuania, Luxembourg, Malta, Moldova, } \\
\text { Netherlands, New Zealand, North Macedonia, Norway, Poland, Portugal, } \\
\text { Romania, Russian Federation, Slovak Republic, Slovenia, Spain, Sweden, } \\
\text { Switzerland, Ukraine, and the United Kingdom }\end{array}$ \\
\hline $\mathrm{LAC}$ & $\begin{array}{l}\text { Argentina, Bolivia, Brazil, Chile, Colombia, Costa Rica, Dominican Republic, } \\
\text { Ecuador, El Salvador, Guatemala, Haiti, Honduras, Jamaica, Mexico, Nicaragua, } \\
\text { Panama, Paraguay, Peru, Uruguay, and Venezuela }\end{array}$ \\
\hline $\begin{array}{l}\text { Low-income } \\
(10)\end{array}$ & $\begin{array}{l}\text { Benin, Congo, Dem. Rep., Eritrea, Haiti, Mozambique, Nepal, Syria, Tajikistan, } \\
\text { Tanzania, and Togo }\end{array}$ \\
\hline $\begin{array}{l}\text { Lower middle- } \\
\text { income }(31)\end{array}$ & $\begin{array}{l}\text { Angola, Bangladesh, Bolivia, Cambodia, Cameroon, Congo, Rep., Cote d'Ivoire } \\
\text { Egypt, El Salvador, Ghana, Honduras, India, Indonesia, Kenya, Kyrgyz Republic, } \\
\text { Moldova, Mongolia, Morocco, Myanmar, Nicaragua, Nigeria, Pakistan, } \\
\text { Philippines, Senegal, Sudan, Tunisia, Ukraine, Uzbekistan, Vietnam, Zambia, and } \\
\text { Zimbabwe }\end{array}$ \\
\hline $\begin{array}{l}\text { Upp } \\
\text { inco }\end{array}$ & $\begin{array}{l}\text { Albania, Algeria, Argentina, Azerbaijan, Belarus, Bosnia and Herzegovina, } \\
\text { Botswana, Brazil, Bulgaria, China, Colombia, Costa Rica, Dominican Republic, } \\
\text { Ecuador, Gabon, Georgia, Guatemala, Iran, Iraq, Jamaica, Jordan, Kazakhstan, } \\
\text { Lebanon, Malaysia, Mauritius, Mexico, Namibia, North Macedonia, Paraguay, } \\
\text { Peru, Romania, Russian Federation, South Africa, Sri Lanka, Thailand, Turkey, } \\
\text { Turkmenistan, and Venezuela }\end{array}$ \\
\hline $\begin{array}{l}\text { Developing } \\
\text { Countries (79) }\end{array}$ & $\begin{array}{l}\text { Albania, Argentina, Azerbaijan, Bangladesh, Belarus, Bolivia, Bosnia and } \\
\text { Herzegovina, Brazil, Cambodia, China, Colombia, Costa Rica, Dominican } \\
\text { Republic, Ecuador, El Salvador, Georgia, Guatemala, Haiti, Honduras, India, } \\
\text { Indonesia, Iran, Iraq, Jordan, Kazakhstan, Kenya, Kyrgyz Republic, Lebanon, } \\
\text { Malaysia, Moldova, Mongolia, Myanmar, Nepal, Pakistan, Philippines, Sri } \\
\text { Lanka, Syria, Tajikistan, Thailand, Turkey, Turkmenistan, Uzbekistan, }\end{array}$ \\
\hline
\end{tabular}




\begin{tabular}{|c|c|}
\hline & $\begin{array}{l}\text { Venezuela, Vietnam, Angola Cameroon, Algeria, Benin , Zimbabwe, Jamaica, } \\
\text { Tunisia, Botswana, Congo, Dem. Rep., Congo, Rep., Egypt, Moldova, North } \\
\text { Macedonia, Russian Federation, Ukraine, Cote d'Ivoire, Eritrea, Gabon, Ghana, } \\
\text { Kenya, Mozambique, Namibia, Mauritius, Nigeria, Senegal, South Africa, } \\
\text { Morocco, Sudan, Tanzania, Togo, Zambia, Bulgaria, Mexico, Nicaragua, } \\
\text { Panama, Paraguay, Peru, and Romania }\end{array}$ \\
\hline $\begin{array}{l}\text { Developed } \\
\text { Countries (46) }\end{array}$ & $\begin{array}{l}\text { Austria, Brunei Darussalam, Australia, Bahrain, New Zealand, Norway, Japan, } \\
\text { Belgium, Hong Kong, Croatia, Czech Republic, Sweden, Switzerland, United } \\
\text { States, United Kingdom, Cyprus, Uruguay, Canada, Chile, Denmark, Estonia, } \\
\text { Finland, France, Hungary, Iceland, Germany, Ireland, Italy, Latvia, Greece, } \\
\text { Lithuania, Luxembourg, Malta, Netherlands, Oman, Poland, Portugal, Saudi } \\
\text { Arabia, Singapore, Slovak Republic, Slovenia, Spain, Israel, and Korea, Rep. }\end{array}$ \\
\hline
\end{tabular}

506

507

508

509

510

511

512

513

514 Table 1: Some prior studiers of the pollution haven hypothesis

\begin{tabular}{|c|c|c|c|}
\hline Author (s) & $\begin{array}{l}\text { Time period, country(s) and } \\
\text { methodology }\end{array}$ & Variables & Results \\
\hline $\begin{array}{l}\text { Cole and } \\
\text { Fredriksson } \\
(2009)\end{array}$ & $\begin{array}{l}\text { 1982-1992, OECD and } \\
\text { developing countries; 3SLS } \\
\text { and Fixed effect }\end{array}$ & $\begin{array}{l}\text { FDI stock and flows, GDP per } \\
\text { capita, manufacturing output, } \\
\text { urban population, inflation }\end{array}$ & $\begin{array}{l}\text { FDI increases pollution. } \mathrm{PHH} \text { is } \\
\text { valid. }\end{array}$ \\
\hline $\begin{array}{l}\text { Tamazian } \\
\text { and Rao } \\
\text { (2010) }\end{array}$ & $\begin{array}{l}\text { 1993-2004, } 24 \\
\text { Transitional economies; } \\
\text { Random effect and GMM }\end{array}$ & $\begin{array}{l}\mathrm{CO}_{2} \text { emissions, FDI , GDP, } \\
\text { Inflation rate, trade openness, } \\
\text { energy use }\end{array}$ & $\begin{array}{l}\text { GDP, trade and energy use } \\
\text { increases } \mathrm{CO}_{2} \text { emissions while } \\
\text { FDI etc. have no impact on } \mathrm{CO}_{2} \\
\text { emissions. EKC is valid. }\end{array}$ \\
\hline $\begin{array}{l}\text { Omri et al. } \\
\text { (2014) }\end{array}$ & $\begin{array}{l}\text { 1990-2011, Europe and } \\
\text { Central Asia, LAC, MENA, } \\
\text { sub-Saharan Africa; GMM }\end{array}$ & $\begin{array}{l}\mathrm{CO}_{2} \text { emissions, FDI, capital } \\
\text { stock, trade openness, } \\
\text { Urbanization, Exchange rate. }\end{array}$ & $\begin{array}{l}\text { All independent variables } \\
\text { increase } \mathrm{CO}_{2} \text { emissions. }\end{array}$ \\
\hline $\begin{array}{l}\text { Neequaye and } \\
\text { Oladi (2015) }\end{array}$ & $\begin{array}{l}2002-2008,27 \text { developing } \\
\text { Countries based on income; } \\
\text { Fixed effects }\end{array}$ & $\begin{array}{l}\text { FDI, GNP, } \mathrm{CO}_{2} \text { emissions, } \\
\text { Trade openness, } \\
\text { stock, employment }\end{array}$ & $\begin{array}{l}\text { FDI increases } \mathrm{CO}_{2} \text { emissions. } \\
\text { EKC is valid. }\end{array}$ \\
\hline $\begin{array}{l}\text { Zhu et al. } \\
\text { (2016) }\end{array}$ & $\begin{array}{l}\text { 1980-2010, ASEAN; Fixed } \\
\text { effects model }\end{array}$ & $\begin{array}{l}\mathrm{CO}_{2} \text { emissions, FDI, trade } \\
\text { openness, population, GDP, } \\
\text { energy use }\end{array}$ & $\begin{array}{l}\text { FDI, population and trade } \\
\text { reduces } \mathrm{CO}_{2} \text { emissions while } \\
\mathrm{GDP} \text { and energy use increases } \\
\mathrm{CO}_{2} \text { emissions. EKC is not } \\
\text { valid and Halo Pollution } \\
\text { Hypothesis is valid. }\end{array}$ \\
\hline $\begin{array}{l}\text { Behera and } \\
\text { Dash (2017) }\end{array}$ & $\begin{array}{l}\text { 1980-2012, South and } \\
\text { Southeast Asian countries; } \\
\text { FMOLS and DOLS }\end{array}$ & $\begin{array}{l}\mathrm{CO}_{2} \text { emission, FDI, primary } \\
\text { energy use, urbanization. }\end{array}$ & $\begin{array}{l}\text { All variables increase } \mathrm{CO}_{2} \\
\text { emissions. }\end{array}$ \\
\hline $\begin{array}{l}\text { Albulescu et } \\
\text { al. (2019) }\end{array}$ & $\begin{array}{l}\text { 1980-2010, } 14 \quad \text { Latin } \\
\text { American countries; } \\
\text { Quantiles regression model }\end{array}$ & $\mathrm{CO}_{2}$ emissions, FDI, income. & $\begin{array}{l}\text { FDI has no impact on pollution. } \\
\text { PHH is not valid but EKC is } \\
\text { valid for low-income group }\end{array}$ \\
\hline
\end{tabular}




\begin{tabular}{|l|l|l|l|}
\hline $\begin{array}{l}\text { Miniesy and } \\
\text { Tarek (2019) }\end{array}$ & $\begin{array}{l}\text { 1996-2016, Asian } \\
\text { developing countries; Fixed } \\
\text { Effects }\end{array}$ & $\mathrm{CO}_{2}$ emissions, FDI. & $\begin{array}{l}\text { FDI increases CO } \mathrm{CO}_{2} \text { emissions } \\
\text { and PHH is valid. }\end{array}$ \\
\hline $\begin{array}{l}\text { Rafique et al. } \\
(2020)\end{array}$ & $1990-2017, \mathrm{BRICS}$ AMG & $\begin{array}{l}\mathrm{CO}_{2} \text { emissions, EG, FDI, } \\
\text { trade openness, energy use, } \\
\text { urbanization }\end{array}$ & $\begin{array}{l}\text { FDI, technological innovation } \\
\text { and financial development have } \\
\text { significantly negative impact, } \\
\text { while the rest of variables have } \\
\text { positive } \\
\text { impact on } \mathrm{CO}_{2} \\
\text { emissions. }\end{array}$ \\
\hline
\end{tabular}

515 Source: Authors compilation

516

517

518 Table 2: Variables description

\begin{tabular}{|l|l|c|l|}
\hline Variables & Description & Label & Source \\
\hline $\begin{array}{l}\text { Carbon Dioxide } \\
\text { Emissions }\end{array}$ & $\begin{array}{l}\text { Burning of fossil fuels and the } \\
\text { manufacture of cement }\end{array}$ & $\mathrm{CO}_{2}$ & $\begin{array}{l}\text { WDI (2020), } \\
\text { Global Carbon } \\
\text { Atlas (2020) }\end{array}$ \\
\hline $\begin{array}{l}\text { Economic } \\
\text { Growth }\end{array}$ & Annual increase in percentage & GDP & WDI, 2020 \\
\hline Energy Usage & Kg of oil equivalent per capita & energy & WDI, 2020 \\
\hline Export & Export of goods and services & FDI & WDI, 2020 \\
\hline $\begin{array}{l}\text { Foreign Direct } \\
\text { Investment }\end{array}$ & FDI inflow & industry & WDI, 2020 \\
\hline $\begin{array}{l}\text { Industry Value } \\
\text { added }\end{array}$ & $\begin{array}{l}\text { Value added in mining, manufacturing, } \\
\text { construction, electricity, water, and gas } \\
\text { industries. }\end{array}$ & Pop & WDI, 2020 \\
\hline Population & Annual increase in percentage & & \\
\hline
\end{tabular}

Table 3: IPS panel unit root test analysis (region based sample countries)

\begin{tabular}{|c|c|c|c|c|c|c|c|c|}
\hline \multirow[b]{2}{*}{ Variables } & \multicolumn{2}{|c|}{ At Level (Asia) } & \multicolumn{2}{|c|}{ At $1^{\text {st }} \Delta$ (Asia) } & \multicolumn{2}{|c|}{ At Level (Africa) } & \multicolumn{2}{|c|}{ At $1^{\text {st }} \Delta$ (Africa) } \\
\hline & $\mathrm{c}$ & $\mathrm{c}$ and $\mathrm{t}$ & $\mathrm{c}$ & $\mathrm{c}$ and $\mathrm{t}$ & $\mathrm{c}$ & $\mathrm{c}$ and $\mathrm{t}$ & $\mathrm{c}$ & $\mathrm{c}$ and $\mathrm{t}$ \\
\hline$f d i_{i t}$ & -1.5 & $-2.50^{* *}$ & $-5.00^{* *}$ & $-4.95^{* *}$ & $-1.74^{* *}$ & $-3.12^{* * *}$ & $-6.76^{* *}$ & $-6.71^{* *}$ \\
\hline$g d p_{i t}$ & $-3.48^{* *}$ & $-3.88^{* *}$ & $-6.7^{* * *}$ & $-6.63^{* *}$ & $-3.92^{* *}$ & $-4.34^{* *}$ & $-7.50^{* * *}$ & $-7.37^{* *}$ \\
\hline pop $_{i t}$ & $-2.04^{* *}$ & $-2.58^{* *}$ & $-3.25^{* *}$ & $-3.09^{* *}$ & $-1.96^{* *}$ & -1.74 & $-1.88^{* *}$ & $-1.48^{* *}$ \\
\hline $\mathrm{CO}_{2 i t}$ & -1.26 & -2.21 & $-4.73^{* *}$ & $-4.92^{* *}$ & -1.21 & $-3.04^{* *}$ & $-5.94^{* *}$ & $-5.94^{* *}$ \\
\hline energy $_{i t}$ & -1.42 & -2.15 & $-4.61^{* *}$ & $-4.97^{* *}$ & -0.8081 & -2.04 & $-4.89^{* *}$ & $-5.16^{* *}$ \\
\hline export ${ }_{i t}$ & -1.67 & $-2.43^{* *}$ & $-1.74^{* * *}$ & $-2.43^{* *}$ & $-1.87^{* *}$ & $-2.47^{* *}$ & $-5.11^{* *}$ & $-5.12^{* * *}$ \\
\hline industry $_{i t}$ & -1.65 & -2.08 & $-4.89^{* *}$ & $-4.95^{* *}$ & $-1.95^{* *}$ & $-2.60^{* *}$ & $-5.24^{* *}$ & $-5.34^{* *}$ \\
\hline & \multicolumn{2}{|c|}{ At Level (Europe) } & \multicolumn{2}{|c|}{ At $1^{\text {st }} \Delta$ (Europe) } & \multicolumn{2}{|c|}{ At Level (LAC) } & \multicolumn{2}{|c|}{ At $1^{\text {st }} \Delta($ LAC $)$} \\
\hline Variables & $\mathrm{c}$ & $\mathrm{c}$ and $\mathrm{t}$ & $\mathrm{c}$ & $\mathrm{c}$ and $\mathrm{t}$ & $\mathrm{c}$ & $\mathrm{c}$ and $\mathrm{t}$ & $\mathrm{c}$ & $\mathrm{c}$ and $\mathrm{t}$ \\
\hline$f d i_{i t}$ & $-2.99^{* *}$ & $-3.58^{* *}$ & $-6.86^{* *}$ & $-6.75^{* *}$ & $-2.99^{* *}$ & $-2.97^{* *}$ & $-5.99^{* *}$ & $-6.00^{* *}$ \\
\hline
\end{tabular}




\begin{tabular}{|c|c|c|c|c|c|c|c|c|}
\hline$g d p_{i t}$ & $-3.02^{* * *}$ & $-3.21^{* *}$ & $-6.13^{* *}$ & $-6.10^{* *}$ & $-3.87^{* *}$ & $-4.02^{* *}$ & $-6.72^{* *}$ & $-6.61^{* *}$ \\
\hline pop $_{i t}$ & $-2.13^{* *}$ & $-2.50^{* *}$ & $-4.25^{* *}$ & $-4.38^{* *}$ & -0.93 & -0.91 & $-2.49^{* *}$ & $-2.48^{* *}$ \\
\hline $\mathrm{CO}_{2 i t}$ & -1.45 & -1.83 & $-5.21^{* *}$ & $-5.63^{* *}$ & -1.54 & -2.31 & $-5.40^{* *}$ & $-5.72^{* *}$ \\
\hline energy $_{i t}$ & -1.33 & -2.24 & $-1.79^{* *}$ & $-2.51^{* *}$ & -1.01 & -1.99 & $-5.20^{* *}$ & $-5.46^{* *}$ \\
\hline $\exp$ ort $_{i t}$ & -1.22 & $-2.42^{* * *}$ & $-4.67^{* *}$ & $-4.68^{* *}$ & -1.46 & -2.32 & $-4.85^{* *}$ & $-4.89^{* * *}$ \\
\hline industry $_{i t}$ & $-1.79^{* * *}$ & -2.23 & $-4.96^{* *}$ & $-5.09^{* *}$ & -1.55 & -2.04 & $-4.60^{* *}$ & $-4.74^{* *}$ \\
\hline
\end{tabular}

523

524

525

526

527

Table 4: IPS panel unit root test analysis (Developed, Developing and Full sample countries)

\begin{tabular}{|c|c|c|c|c|c|c|c|c|c|c|c|c|}
\hline \multirow{2}{*}{$\begin{array}{l}\text { Variable } \\
\mathrm{s}\end{array}$} & \multicolumn{2}{|c|}{$\begin{array}{c}\text { At Level } \\
\text { (Developed } \\
\text { countries) }\end{array}$} & \multicolumn{2}{|c|}{$\begin{array}{c}\text { At } 1^{\text {st }} \\
\Delta(\text { Developed } \\
\text { countries })\end{array}$} & \multicolumn{2}{|c|}{$\begin{array}{c}\text { At Level } \\
\text { (Developing } \\
\text { countries) }\end{array}$} & \multicolumn{2}{|c|}{$\begin{array}{c}\text { At } 1^{\text {st }} \Delta \\
\text { (Developing } \\
\text { countries) }\end{array}$} & \multicolumn{2}{|c|}{$\begin{array}{c}\text { At Level (Full } \\
\text { Sample) }\end{array}$} & \multicolumn{2}{|c|}{$\begin{array}{l}\text { At } 1 \text { st } \Delta \text { (Full } \\
\text { Sample) }\end{array}$} \\
\hline & $\mathrm{c}$ & $\mathrm{c}$ and $\mathrm{t}$ & $\mathrm{c}$ & $\mathrm{c}$ and $\mathrm{t}$ & $\mathrm{c}$ & $c$ and $t$ & $\mathrm{c}$ & $\mathrm{c}$ and $\mathrm{t}$ & $\mathrm{c}$ & $\mathrm{c}$ and $\mathrm{t}$ & $\mathrm{c}$ & $\mathrm{c}$ and $\mathrm{t}$ \\
\hline$f d i_{i t}$ & -1.61 & $-2.79^{* *}$ & $-5.78^{* *}$ & $-5.72^{* *}$ & $-2.88^{* *}$ & $-3.60^{* * *}$ & $-6.80^{* *}$ & $-6.73^{* * *}$ & $-2.04^{* *}$ & $-3.06^{* * *}$ & $-6.13^{* *}$ & $-6.07^{* *}$ \\
\hline$g d p_{i t}$ & $3.56^{* *}$ & $-3.92^{* *}$ & $-6.98^{* *}$ & $-6.90^{* *}$ & $-3.37^{* *}$ & $-3.55^{* * *}$ & $-6.20^{* *}$ & $-6.15^{* *}$ & $-3.48^{* *}$ & $-3.78^{* * *}$ & $-6.68^{* *}$ & $-6.61^{* *}$ \\
\hline pop $_{i t}$ & $1.97^{-}$ & -2.11 & $-2.43^{* *}$ & $-2.98^{* *}$ & -1.83 & -2.30 & $-4.12^{* *}$ & $-4.22^{* *}$ & $-1.89^{* *}$ & -2.16 & $-3.00^{* *}$ & $-2.94^{* * *}$ \\
\hline $\mathrm{CO}_{2 i t}$ & -1.31 & $-2.46^{* *}$ & $-5.21^{* *}$ & $-5.39^{* *}$ & -1.46 & -1.80 & $-5.23^{* *}$ & $-5.67^{* *}$ & -1.37 & -2.25 & $-5.22^{* *}$ & $-5.49^{* *}$ \\
\hline energy $_{i t}$ & -1.24 & -2.17 & $-4.67^{* *}$ & $-4.98^{* * *}$ & -1.29 & -2.30 & $-1.81^{* * *}$ & $-2.85^{* *}$ & -1.36 & -2.21 & $-1.77^{* *}$ & $-2.57^{* * *}$ \\
\hline $\exp _{o r t}{ }_{i t}$ & $1.79^{-}$ & $-2.52^{* *}$ & $-5.27^{* *}$ & $-5.30^{* *}$ & -1.07 & -2.28 & $-4.47^{* *}$ & $-4.48^{* *}$ & -1.55 & $-2.42^{* * *}$ & $-4.96^{* *}$ & $-5.00^{* *}$ \\
\hline industry $_{i t}$ & $1.86^{* * *}$ & -2.29 & $-4.96^{* *}$ & $-5.05^{* *}$ & -1.64 & -2.19 & $-4.87^{* *}$ & $-5.01^{* *}$ & $-1.74^{* *}$ & -2.24 & $-4.95^{* *}$ & $-5.05^{* *}$ \\
\hline \multicolumn{13}{|c|}{ IPS panel unit root test analysis ( Income based sample countries) } \\
\hline & \multicolumn{2}{|c|}{$\begin{array}{l}\text { At Level (Low- } \\
\text { income) }\end{array}$} & \multicolumn{2}{|c|}{$\begin{array}{c}\text { At } 1^{\text {st }} \Delta(\text { Low- } \\
\text { income })\end{array}$} & \multicolumn{2}{|c|}{$\begin{array}{l}\text { At Level (Lower- } \\
\text { middle-income) }\end{array}$} & \multicolumn{2}{|c|}{$\begin{array}{l}\text { At 1st } \Delta \text { (Lower- } \\
\text { middle-income) }\end{array}$} & \multicolumn{2}{|c|}{$\begin{array}{l}\text { At Level (Upper- } \\
\text { middle-income) }\end{array}$} & \multicolumn{2}{|c|}{$\begin{array}{l}\text { At } 1^{\text {st }} \Delta \text { (Upper- } \\
\text { middle-income })\end{array}$} \\
\hline Variables & $\mathrm{c}$ & $\mathrm{t}^{\mathrm{c} \text { and }}$ & c & $\mathrm{t}^{\mathrm{c} \text { and }}$ & $\mathrm{c}$ & $\mathrm{c}$ and $\mathrm{t}$ & $\mathrm{c}$ & $\mathrm{t}^{\mathrm{c} \text { and }}$ & $\mathrm{c}$ & $\begin{array}{l}\mathrm{c} \text { and } \\
\mathrm{t}\end{array}$ & $\mathrm{c}$ & $\mathrm{c}$ and $\mathrm{t}$ \\
\hline$f d i_{i t}$ & -1.65 & $-2.88^{* *}$ & $-5.84^{* *}$ & $-5.82^{* *}$ & -1.57 & $-2.79^{* *}$ & $-6.12^{* *}$ & $-6.09^{* *}$ & -1.63 & -2.27 & $-6.13^{* *}$ & $-6.07^{* * *}$ \\
\hline$g d p_{i t}$ & $\begin{array}{c}- \\
3.36^{* *}\end{array}$ & $-4.00^{* *}$ & $-7.31^{* *}$ & $-7.16^{* *}$ & $-3.40^{* *}$ & $-3.95^{* *}$ & $-7.12^{* *}$ & $-7.03^{* *}$ & $-3.74^{* *}$ & $\begin{array}{c}- \\
3.88^{* * *} \\
\end{array}$ & $-6.68^{* *}$ & $-6.61^{* *}$ \\
\hline pop $_{i t}$ & -0.95 & $-3.58^{* * *}$ & $-2.53^{* *}$ & $-4.98^{* *}$ & -1.58 & -1.83 & $-1.98^{* *}$ & $-2.75^{* *}$ & $-2.55^{* *}$ & -1.96 & $-3.00^{* * *}$ & $-2.94^{* * *}$ \\
\hline $\mathrm{CO}_{2 i t}$ & -0.76 & -1.57 & $-4.13^{* *}$ & $-4.40^{* *}$ & -1.10 & -2.18 & $-5.40^{* *}$ & $-5.66^{* *}$ & -1.64 & -2.23 & $-5.22^{* *}$ & $-5.49^{* * *}$ \\
\hline energy $_{i t}$ & -0.83 & -1.87 & $-3.91^{* *}$ & $-4.27^{* *}$ & -1.07 & -1.92 & $-4.66^{* *}$ & $-5.08^{* *}$ & -1.48 & -2.30 & $-2.11^{* *}$ & $-3.41^{* * *}$ \\
\hline $\exp _{o r t} t_{i t}$ & -1.35 & -2.58 & $-4.92^{* *}$ & $-4.93^{* *}$ & -1.68 & $-2.66^{* *}$ & $-5.71^{* *}$ & $-5.76^{* *}$ & $-1.92^{* *}$ & $2 . \overline{-}$ & $-4.95^{* *}$ & $-4.99^{* *}$ \\
\hline industry $_{i t}$ & -1.37 & $-2.59^{* * *}$ & $-5.50^{* *}$ & $-5.54^{* *}$ & $-1.94^{* *}$ & -2.31 & $-5.00^{* *}$ & $-5.10^{* *}$ & $-1.92^{* * *}$ & $2.95^{* *}$ & $-4.94^{* *}$ & $-5.05^{* * *}$ \\
\hline
\end{tabular}

528 
Table 5: Random-effects and GMM estimates (Regional wise analysis)

\begin{tabular}{|c|c|c|c|c|c|c|c|c|}
\hline \multirow[b]{2}{*}{ Variables } & \multicolumn{2}{|c|}{ Asia } & \multicolumn{2}{|c|}{ Africa } & \multicolumn{2}{|c|}{ LAC } & \multicolumn{2}{|c|}{ Europe } \\
\hline & $\mathrm{RE}$ & GMM & RE & GMM & RE & GMM & RE & GMM \\
\hline Constant & $\begin{array}{l}-1.067 \\
(0.326) \\
\end{array}$ & $\begin{array}{l}-0.551 \\
(0.475) \\
\end{array}$ & $\begin{array}{l}-1.113 \\
(0.286) \\
\end{array}$ & $\begin{array}{l}-1.975 \\
(0.174) \\
\end{array}$ & $\begin{array}{l}-0.970 \\
(0.366) \\
\end{array}$ & $\begin{array}{l}-0.432 \\
(0.841) \\
\end{array}$ & $\begin{array}{l}-1.137 \\
(0.612) \\
\end{array}$ & $\begin{array}{l}-1.843 \\
(0.745) \\
\end{array}$ \\
\hline$f d i_{i t}$ & $\begin{array}{c}9.68 \mathrm{e}-07^{* * *} \\
(0.000)\end{array}$ & $\begin{array}{c}3.00 \mathrm{e}-06^{* *} \\
(0.031)\end{array}$ & $\begin{array}{c}3.02 \mathrm{E}-05^{* * *} \\
(0.000)\end{array}$ & $\begin{array}{l}0.001^{* *} \\
(0.031)\end{array}$ & $\begin{array}{c}1.36 \mathrm{E}-07 \\
(0.125)\end{array}$ & $\begin{array}{c}1.18 \mathrm{E}-07 \\
(0.312)\end{array}$ & $\begin{array}{c}1.13 \mathrm{E}-07 \\
(0.311)\end{array}$ & $\begin{array}{c}-1.41 \mathrm{E}-07 \\
(0.729) \\
\end{array}$ \\
\hline$G D P_{i t}$ & $\begin{array}{c}0.0007^{* * * *} \\
(0.001)\end{array}$ & $\begin{array}{l}0.002^{* * * *} \\
(0.000)\end{array}$ & $\begin{array}{l}0.005^{* * *} \\
(0.004)\end{array}$ & $\begin{array}{l}0.003^{* * *} \\
(0.009)\end{array}$ & $\begin{array}{l}0.001^{*} \\
(0.102)\end{array}$ & $\begin{array}{c}0.002 \\
(0.196)\end{array}$ & $\begin{array}{c}-0.001^{* * *} \\
(0.000)\end{array}$ & $\begin{array}{l}0.002^{* * *} \\
(0.009)\end{array}$ \\
\hline Pop $_{i t}$ & $\begin{array}{c}-0.005^{* * *} \\
(0.004)\end{array}$ & $\begin{array}{l}0.020^{* *} \\
(0.045)\end{array}$ & $\begin{array}{l}0.039^{* * *} \\
(0.004)\end{array}$ & $\begin{array}{l}0.019^{* *} \\
(0.045)\end{array}$ & $\begin{array}{c}-0.150^{* * *} \\
(0.004) \\
\end{array}$ & $\begin{array}{c}-0.067^{* *} \\
(0.041) \\
\end{array}$ & $\begin{array}{c}0.004^{* * *} \\
(0.007)\end{array}$ & $\begin{array}{l}0.085^{* * *} \\
(0.002)\end{array}$ \\
\hline$e^{e n e r g} y_{i t}$ & $\begin{array}{l}1.131^{\text {**** }} \\
(0.000)\end{array}$ & $\begin{array}{l}1.039^{* * * *} \\
(0.000)\end{array}$ & $\begin{array}{l}1.051^{* * * *} \\
(0.000)\end{array}$ & $\begin{array}{c}1.1205^{* * * *} \\
(0.006)\end{array}$ & $\begin{array}{l}1.178^{* * * *} \\
(0.000)\end{array}$ & $\begin{array}{c}0.775^{* * *} \\
(0.008) \\
\end{array}$ & $\begin{array}{c}1.0143^{* * * *} \\
(0.000)\end{array}$ & $\begin{array}{l}0.641^{* * * *} \\
(0.002)\end{array}$ \\
\hline $\exp o r t_{i t}$ & $\begin{array}{l}0.001^{* * * *} \\
(0.001)\end{array}$ & $\begin{array}{l}0.001^{* * * *} \\
(0.005)\end{array}$ & $\begin{array}{l}-0.002 \\
(0.131) \\
\end{array}$ & $\begin{array}{l}-0.001 \\
(0.125) \\
\end{array}$ & $\begin{array}{c}0.001^{* * * *} \\
(0.004)\end{array}$ & $\begin{array}{c}0.001^{* * * *} \\
(0.005)\end{array}$ & $\begin{array}{c}-0.001^{* * *} \\
(0.000)\end{array}$ & $\begin{array}{c}-0.001 \\
(0.415) \\
\end{array}$ \\
\hline industry $_{i t}$ & $\begin{array}{l}0.002^{* * * *} \\
(0.008)\end{array}$ & $\begin{array}{l}0.004^{* * *} \\
(0.007)\end{array}$ & $\begin{array}{l}-0.001 \\
(0.508)\end{array}$ & $\begin{array}{l}-0.0012 \\
(0.128) \\
\end{array}$ & $\begin{array}{l}0.002^{* *} \\
(0.012)\end{array}$ & $\begin{array}{l}0.009^{* *} \\
(0.028)\end{array}$ & $\begin{array}{c}0.001^{* * *} \\
(0.001)\end{array}$ & $\begin{array}{l}0.001^{* * *} \\
(0.008)\end{array}$ \\
\hline Countries & 37 & 37 & 26 & 26 & 20 & 20 & 39 & 39 \\
\hline $\mathrm{N}$ & 925 & 888 & 650 & 624 & 500 & 480 & 975 & 936 \\
\hline Wald $C h i^{2}$ & 254.79 & - & 254.48 & - & 750.87 & - & 819.51 & - \\
\hline Prob $>C h i^{2}$ & 0.000 & - & 0.000 & - & 0.000 & - & 0.000 & - \\
\hline $\begin{array}{l}\text { AR (2) P- } \\
\text { value }\end{array}$ & - & 0.290 & - & 0.461 & - & 0.635 & - & 0.914 \\
\hline $\begin{array}{c}\text { Sargan/Hans } \\
\text { en P-value }\end{array}$ & - & 0.687 & - & 0.999 & - & 0.996 & - & 0.836 \\
\hline
\end{tabular}

Table 6: Random-effects and GMM estimates (developing, developed and full sample analysis)

\begin{tabular}{|c|c|c|c|c|c|c|}
\hline \multirow[b]{2}{*}{ Variables } & \multicolumn{2}{|c|}{ Developing countries } & \multicolumn{2}{|c|}{ Developed countries } & \multicolumn{2}{|c|}{ Full sample countries } \\
\hline & RE & GMM & RE & GMM & RE & GMM \\
\hline Constant & $\begin{array}{l}0.5148 \\
(0.291)\end{array}$ & $\begin{array}{l}-0.5468 \\
(0.128) \\
\end{array}$ & $\begin{array}{r}-1.2319 \\
(0.712) \\
\end{array}$ & $\begin{array}{l}-0.1864 \\
(0.702)\end{array}$ & $\begin{array}{c}-0.6244 \\
(0.461)\end{array}$ & $\begin{array}{r}-0.3907 \\
(0.282) \\
\end{array}$ \\
\hline$f d i_{i t}$ & $\begin{array}{c}1.06 \mathrm{E}-06^{* * *} \\
(0.015)\end{array}$ & $\begin{array}{c}4.47 \mathrm{E}-07^{* *} \\
(0.031)\end{array}$ & $\begin{array}{c}3.51 \mathrm{E}-07 \\
(0.112)\end{array}$ & $\begin{array}{c}1.21 \mathrm{E}-07 \\
(0.372)\end{array}$ & $\begin{array}{c}4.24 \mathrm{E}-07^{* * * *} \\
(0.004)\end{array}$ & $\begin{array}{c}4.27 \mathrm{E}-07^{* *} \\
(0.012)\end{array}$ \\
\hline$G D P_{i t}$ & $\begin{array}{c}0.0014^{* * * *} \\
(0.004)\end{array}$ & $\begin{array}{c}0.0039^{* * * *} \\
(0.003)\end{array}$ & $\begin{array}{c}-0.0012^{* * * *} \\
(0.000)\end{array}$ & $\begin{array}{c}0.0005^{* * * *} \\
(0.009)\end{array}$ & $\begin{array}{c}0.0011^{* * *} \\
(0.011)\end{array}$ & $\begin{array}{c}0.0027^{* *} \\
(0.015)\end{array}$ \\
\hline Pop $_{i t}$ & $\begin{array}{c}-0.0250^{* * * *} \\
(0.001)\end{array}$ & $\begin{array}{c}-0.0212^{* *} \\
(0.045)\end{array}$ & $\begin{array}{l}0.0007 \\
(0.807)\end{array}$ & $\begin{array}{l}0.0073 \\
(0.479)\end{array}$ & $\begin{array}{c}-0.0115^{*} \\
(0.106)\end{array}$ & $\begin{array}{l}-0.0048 \\
(0.751)\end{array}$ \\
\hline$e^{e n e r g} y_{i t}$ & $\begin{array}{c}1.3153^{* * *} \\
(0.000)\end{array}$ & $\begin{array}{c}0.4612^{* * * *} \\
(0.006)\end{array}$ & $\begin{array}{c}0.9739^{* * * *} \\
(0.000)\end{array}$ & $\begin{array}{c}0.8593^{* * * *} \\
(0.002)\end{array}$ & $\begin{array}{c}1.2141^{* * * *} \\
(0.000)\end{array}$ & $\begin{array}{c}0.1413^{* * *} \\
(0.046)\end{array}$ \\
\hline $\exp _{o r t}{ }_{i t}$ & $\begin{array}{c}0.0011^{* *} \\
(0.013)\end{array}$ & $\begin{array}{l}0.001^{* *} \\
(0.025)\end{array}$ & $\begin{array}{c}-0.0002 \\
(0.223)\end{array}$ & $\begin{array}{l}-0.0005 \\
(0.463)\end{array}$ & $\begin{array}{c}0.0005^{* * * *} \\
(0.005)\end{array}$ & $\begin{array}{c}0.0007^{* * * *} \\
(0.005)\end{array}$ \\
\hline industry $_{i t}$ & $\begin{array}{c}\text { 6.68E-06 } \\
(0.990)\end{array}$ & $\begin{array}{l}-0.0038 \\
(0.347)\end{array}$ & $\begin{array}{c}0.0032^{* * * *} \\
(0.000)\end{array}$ & $\begin{array}{c}0.0013^{* * * *} \\
(0.000)\end{array}$ & $\begin{array}{c}0.0014^{* * * * *} \\
(0.001)\end{array}$ & $\begin{array}{c}0.0045^{* * * *} \\
(0.008)\end{array}$ \\
\hline
\end{tabular}




\begin{tabular}{|c|c|c|c|c|c|c|}
\hline Countries & 79 & 79 & 44 & 44 & 125 & 125 \\
\hline $\mathrm{N}$ & 1975 & 1896 & 1100 & 1056 & 3125 & 3000 \\
\hline Wald $\mathrm{Chi}^{2}$ & 856.08 & ----- & 221.91 & ----- & 507.05 & ----- \\
\hline Prob>Chi & 0.000 & ------ & 0.000 & ------ & 0.000 & ------ \\
\hline $\begin{array}{c}\text { AR (2) P- } \\
\text { value }\end{array}$ & ------ & 0.868 & ----- & 0.352 & ----- & 0.862 \\
\hline $\begin{array}{l}\text { Sargan/Hansen } \\
\text { P-value }\end{array}$ & ------ & 0.198 & ------ & 0.733 & ------ & 0.156 \\
\hline
\end{tabular}

Table 7: Random-effects and GMM estimates (Income wise analysis)

\begin{tabular}{|c|c|c|c|c|c|c|}
\hline \multirow[b]{2}{*}{ Variables } & \multicolumn{2}{|c|}{ Low-income } & \multicolumn{2}{|c|}{ Lower-middle-income } & \multicolumn{2}{|c|}{ Upper-middle-income } \\
\hline & $\mathrm{RE}$ & GMM & $\mathrm{RE}$ & GMM & $\mathrm{RE}$ & GMM \\
\hline Constant & $\begin{array}{r}-0.6354 \\
(0.091)\end{array}$ & $\begin{array}{l}-0.5712 \\
(0.128)\end{array}$ & $\begin{array}{l}-0.6793 \\
(0.768)\end{array}$ & $\begin{array}{l}-0.1459 \\
(0.711)\end{array}$ & $\begin{array}{c}-1.0536 \\
(0.461)\end{array}$ & $\begin{array}{r}-0.1447 \\
(0.764)\end{array}$ \\
\hline$f d i_{i t}$ & $\begin{array}{c}0.0001^{* * * *} \\
(0.000)\end{array}$ & $\begin{array}{c}0.0001^{* * *} \\
(0.001)\end{array}$ & $\begin{array}{c}5.61 \mathrm{E}-06^{* * *} \\
(0.000)\end{array}$ & $\begin{array}{c}1.49 \mathrm{E}-06^{* * *} \\
(0.002)\end{array}$ & $\begin{array}{c}9.30 \mathrm{E}-07^{* *} \\
(0.011)\end{array}$ & $\begin{array}{c}1.21 \mathrm{E}-07^{* *} \\
(0.012)\end{array}$ \\
\hline$G D P_{i t}$ & $\begin{array}{c}0.0003^{* * *} \\
(0.004)\end{array}$ & $\begin{array}{c}0.0006^{* * *} \\
(0.003)\end{array}$ & $\begin{array}{c}0.0064^{* * *} \\
(0.000)\end{array}$ & $\begin{array}{c}0.0058^{* * * *} \\
(0.002)\end{array}$ & $\begin{array}{c}0.0007^{* *} \\
(0.011)\end{array}$ & $\begin{array}{l}0.0021^{* *} \\
(0.015)\end{array}$ \\
\hline Pop $_{i t}$ & $\begin{array}{c}-0.0216^{* *} \\
(0.029)\end{array}$ & $\begin{array}{c}-0.0847^{* *} \\
(0.041)\end{array}$ & $\begin{array}{c}-0.0968^{* * *} \\
(0.007)\end{array}$ & $\begin{array}{c}-0.0213^{* * *} \\
(0.006)\end{array}$ & $\begin{array}{c}-0.0179^{* * * *} \\
(0.006)\end{array}$ & $\begin{array}{c}-0.0039^{* * * *} \\
(0.001)\end{array}$ \\
\hline$e^{e n e r g} y_{i t}$ & $\begin{array}{c}1.5933^{* * *} \\
(0.000)\end{array}$ & $\begin{array}{c}1.3985^{* * *} \\
(0.006)\end{array}$ & $\begin{array}{c}1.3678^{* * * *} \\
(0.000)\end{array}$ & $\begin{array}{c}0.2555^{* * *} \\
(0.002)\end{array}$ & $\begin{array}{c}1.1436^{* * * *} \\
(0.000)\end{array}$ & $\begin{array}{c}0.7333^{* *} \\
(0.018)\end{array}$ \\
\hline $\exp o r t_{i t}$ & $\begin{array}{c}-0.0018^{*} \\
(0.081)\end{array}$ & $\begin{array}{c}-0.0128^{*} \\
(0.059)\end{array}$ & $\begin{array}{l}-0.0005 \\
(0.411) \\
\end{array}$ & $\begin{array}{l}-0.0001 \\
(0.563)\end{array}$ & $\begin{array}{c}0.0011^{* * * *} \\
(0.003)\end{array}$ & $\begin{array}{c}0.0024^{* * *} \\
(0.005)\end{array}$ \\
\hline industry $_{i t}$ & $\begin{array}{l}-0.0005 \\
(0.776) \\
\end{array}$ & $\begin{array}{l}-0.0177 \\
(0.417) \\
\end{array}$ & $\begin{array}{l}0.0005 \\
(0.615) \\
\end{array}$ & $\begin{array}{l}0.0004 \\
(0.452) \\
\end{array}$ & $\begin{array}{r}-0.0001 \\
(0.875) \\
\end{array}$ & $\begin{array}{l}-0.0076 \\
(0.801) \\
\end{array}$ \\
\hline Countries & 10 & 10 & 31 & 31 & 38 & 38 \\
\hline $\mathrm{N}$ & 250 & 240 & 775 & 744 & 950 & 912 \\
\hline Wald $C h i^{2}$ & 253.28 & ------ & 239.01 & ------ & 308.60 & ------ \\
\hline Prob $>C h i^{2}$ & 0.000 & ------ & 0.000 & ------ & 0.000 & ------ \\
\hline AR (2) P-value & ------ & 0.396 & ------ & 0.777 & ------ & 0.860 \\
\hline $\begin{array}{c}\text { Sargan/Hansen } \\
\text { P-value }\end{array}$ & ------ & 1.000 & ------ & 0.406 & ------ & 0.782 \\
\hline
\end{tabular}


Table 8: D-H Granger causality test results for region-wise countries

\begin{tabular}{|l|c|c|c|c|r|r|r|r|}
\hline & \multicolumn{2}{|c|}{ Asia } & \multicolumn{2}{c|}{ Africa } & \multicolumn{2}{c|}{ LAC } & \multicolumn{2}{c|}{ Europe } \\
\hline Null Hypothesis & Z-statistic & P-value & Z-statistic & P-value & Z-statistic & P-value & Z-statistic & P-value \\
\hline $\mathrm{CO}_{2} \rightarrow \mathrm{FDI}$ & $2.9971^{* * * *}$ & 0.0027 & $8.0157^{* * *}$ & 0.000 & $3.6228^{* * * *}$ & 0.0003 & $2.332^{* * *}$ & 0.0197 \\
\hline $\mathrm{FDI} \rightarrow \mathrm{CO}_{2}$ & $11.6612^{* * *}$ & 0.000 & $14.6882^{* * *}$ & 0.000 & $5.4643^{* * * *}$ & 0.000 & $2.8487^{* * * *}$ & 0.0044 \\
\hline $\mathrm{CO}_{2} \rightarrow$ Energy & $4.9986^{* * *}$ & 0.000 & $16.4041^{* * *}$ & 0.000 & $5.3825^{* * *}$ & 0.000 & $4.1935^{* * *}$ & 0.000 \\
\hline Energy $\rightarrow \mathrm{CO}_{2}$ & $7.8916^{* * *}$ & 0.000 & $7.2841^{* * *}$ & 0.000 & $4.4868^{* * *}$ & 0.000 & $5.1837^{* * * *}$ & 0.000 \\
\hline $\mathrm{CO}_{2} \rightarrow$ export & $5.6891^{* * * *}$ & 0.000 & $3.2049^{* * *}$ & 0.0014 & $3.5254^{* * *}$ & 0.0004 & $11.1934^{* * *}$ & 0.000 \\
\hline export $\rightarrow \mathrm{CO}_{2}$ & $12.0308^{* * *}$ & 0.000 & $5.6423^{* * *}$ & 0.000 & $4.7486^{* * *}$ & 0.000 & $2.2289^{* *}$ & 0.0258 \\
\hline $\mathrm{CO}_{2} \rightarrow$ industry & $2.6738^{* * *}$ & 0.0075 & $3.1427^{* * *}$ & 0.0017 & $1.7056^{* *}$ & 0.0501 & $8.9128^{* * *}$ & 0.000 \\
\hline industry $\rightarrow \mathrm{CO}_{2}$ & $8.3389^{* * *}$ & 0.000 & $4.6311^{* * *}$ & 0.000 & $3.4345^{* * *}$ & 0.000 & $6.1807^{* * *}$ & 0.000 \\
\hline $\mathrm{CO}_{2} \rightarrow$ pop & $14.7819^{* * *}$ & 0.000 & $2.3118^{* *}$ & 0.0208 & $10.9735^{* * * *}$ & 0.000 & $5.216^{* * *}$ & 0.000 \\
\hline $\mathrm{pop} \rightarrow \mathrm{CO}_{2}$ & $24.7192^{* * *}$ & 0.000 & $32.3928^{* * *}$ & 0.000 & $22.8244^{* * *}$ & 0.000 & $9.2301^{* * * *}$ & 0.000 \\
\hline
\end{tabular}

D-H. Granger causality test results for full sampled and sub categories countries

\begin{tabular}{|c|c|c|c|c|c|c|}
\hline & \multicolumn{2}{|c|}{ Full Sample } & \multicolumn{2}{|c|}{ Developing } & \multicolumn{2}{|l|}{ Developed } \\
\hline Null Hypothesis & Z-statistic & P-value & Z-statistic & P-value & Z-statistic & P-value \\
\hline $\mathrm{CO}_{2} \rightarrow \mathrm{FDI}$ & $8.2629^{* * * *}$ & 0.000 & $8.6227^{* * *}$ & 0.000 & $2.3556^{* *}$ & 0.0185 \\
\hline $\mathrm{FDI} \rightarrow \mathrm{CO}_{2}$ & $17.3708^{* * * *}$ & 0.000 & $17.6415^{* * *}$ & 0.000 & $5.2814^{* * * *}$ & 0.000 \\
\hline $\begin{array}{ll}\mathrm{CO}_{2} & \rightarrow \\
\text { Energy } & \end{array}$ & $3.9986^{* * * *}$ & 0.000 & $22.2906^{* * * *}$ & 0.000 & $5.3825^{* * *}$ & 0.000 \\
\hline $\begin{array}{l}\text { Energy } \\
\mathrm{CO}_{2}\end{array}$ & $6.8916^{* * *}$ & 0.000 & $12.8043^{* * * *}$ & 0.000 & $9.3107^{* * *}$ & 0.000 \\
\hline $\mathrm{CO}_{2} \rightarrow$ export & $12.5403^{* * * *}$ & 0.000 & $8.7076^{* * *}$ & 0.000 & $6.9253^{* * * *}$ & 0.000 \\
\hline export $\longrightarrow \mathrm{CO}_{2}$ & $12.8798^{* * * *}$ & 0.000 & $12.5113^{* * *}$ & 0.000 & $4.7486^{* * * *}$ & 0.000 \\
\hline $\begin{array}{ll}\mathrm{CO}_{2} & \rightarrow \\
\text { industry }\end{array}$ & $8.9024^{* * * *}$ & 0.000 & $6.3399^{* * *}$ & 0.000 & $6.9253^{* * * *}$ & 0.000 \\
\hline $\begin{array}{l}\text { industry } \\
\mathrm{CO}_{2}\end{array}$ & $11.3379^{* * * *}$ & 0.000 & $9.3513^{* * *}$ & 0.000 & $5.5949^{* * * *}$ & 0.000 \\
\hline $\mathrm{CO}_{2} \rightarrow$ pop & $16.7339^{* * * *}$ & 0.000 & $16.2228^{* * * *}$ & 0.000 & $6.0795^{* * *}$ & 0.000 \\
\hline pop $\rightarrow \mathrm{CO}_{2}$ & $42.953^{* * * *}$ & 0.000 & $43.3389^{* * * *}$ & 0.000 & $13.8317^{* * *}$ & 0.000 \\
\hline
\end{tabular}

D.H. Granger causality test results for income wise countries

\begin{tabular}{|l|c|l|c|l|l|l|}
\hline & \multicolumn{2}{|c|}{ Low Income } & \multicolumn{2}{c|}{ Lower-middle Income } & \multicolumn{2}{c|}{$\begin{array}{c}\text { Upper-middle } \\
\text { Income }\end{array}$} \\
\hline Null Hypothesis & Z-statistic & P-value & Z-statistic & P-value & Z-statistic & P-value \\
\hline $\mathrm{CO}_{2} \rightarrow$ FDI & $3.6447^{* * *}$ & 0.0003 & $4.094^{* * * *}$ & 0.000 & $6.8652^{* * *}$ & 0.000 \\
\hline $\mathrm{FDI} \rightarrow \mathrm{CO}_{2}$ & $7.1282^{* * * *}$ & 0.000 & $10.8592^{* * * *}$ & 0.000 & $11.9717^{* * *}$ & 0.000 \\
\hline $\mathrm{CO}_{2} \rightarrow$ Energy & $10.077^{* * *}$ & 0.000 & $12.4127^{* * *}$ & 0.000 & $15.7591^{* * * *}$ & 0.000 \\
\hline Energy $\rightarrow \mathrm{CO}_{2}$ & $4.7391^{* * *}$ & 0.000 & $8.7517^{* * *}$ & 0.000 & $8.1262^{* * *}$ & 0.000 \\
\hline $\mathrm{CO}_{2} \rightarrow$ export & $3.7054^{* * *}$ & 0.000 & $5.0845^{* * *}$ & 0.000 & $6.0618^{* * *}$ & 0.000 \\
\hline export $\rightarrow \mathrm{CO}_{2}$ & $4.8791^{* * *}$ & 0.000 & $10.8761^{* * *}$ & 0.000 & $5.7132^{* * *}$ & 0.000 \\
\hline $\begin{array}{l}\mathrm{CO}_{2} \rightarrow \\
\text { industry }\end{array}$ & $1.9228^{* * *}$ & 0.0545 & $2.395^{* *}$ & 0.0166 & $5.9916^{* * *}$ & 0.000 \\
\hline
\end{tabular}




\begin{tabular}{|l|c|l|l|l|l|l|}
\hline $\begin{array}{l}\text { industry } \\
\mathrm{CO}_{2}\end{array}$ & $1.4008^{* *}$ & 0.1613 & $6.342^{* * *}$ & 0.000 & $7.0365^{* * *}$ & 0.000 \\
\hline $\mathrm{CO}_{2} \rightarrow$ pop & $8.1584^{* * *}$ & 0.000 & $6.6295^{* * *}$ & 0.000 & $13.2179^{* * *}$ & 0.000 \\
\hline pop $\rightarrow \mathrm{CO}_{2}$ & $19.8477^{* * *}$ & 0.000 & $36.8424^{* * *}$ & 0.000 & $19.0304^{* * *}$ & 0.000 \\
\hline
\end{tabular}

Figure 1 Analytical Framework

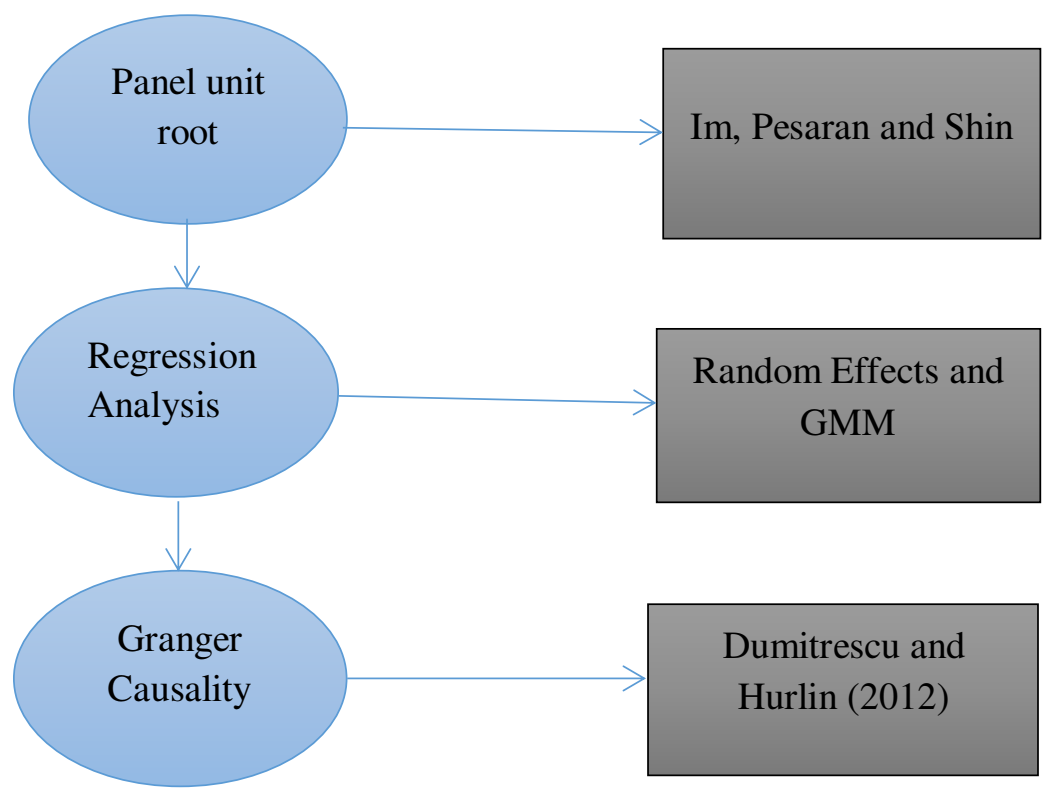




\section{Figures}

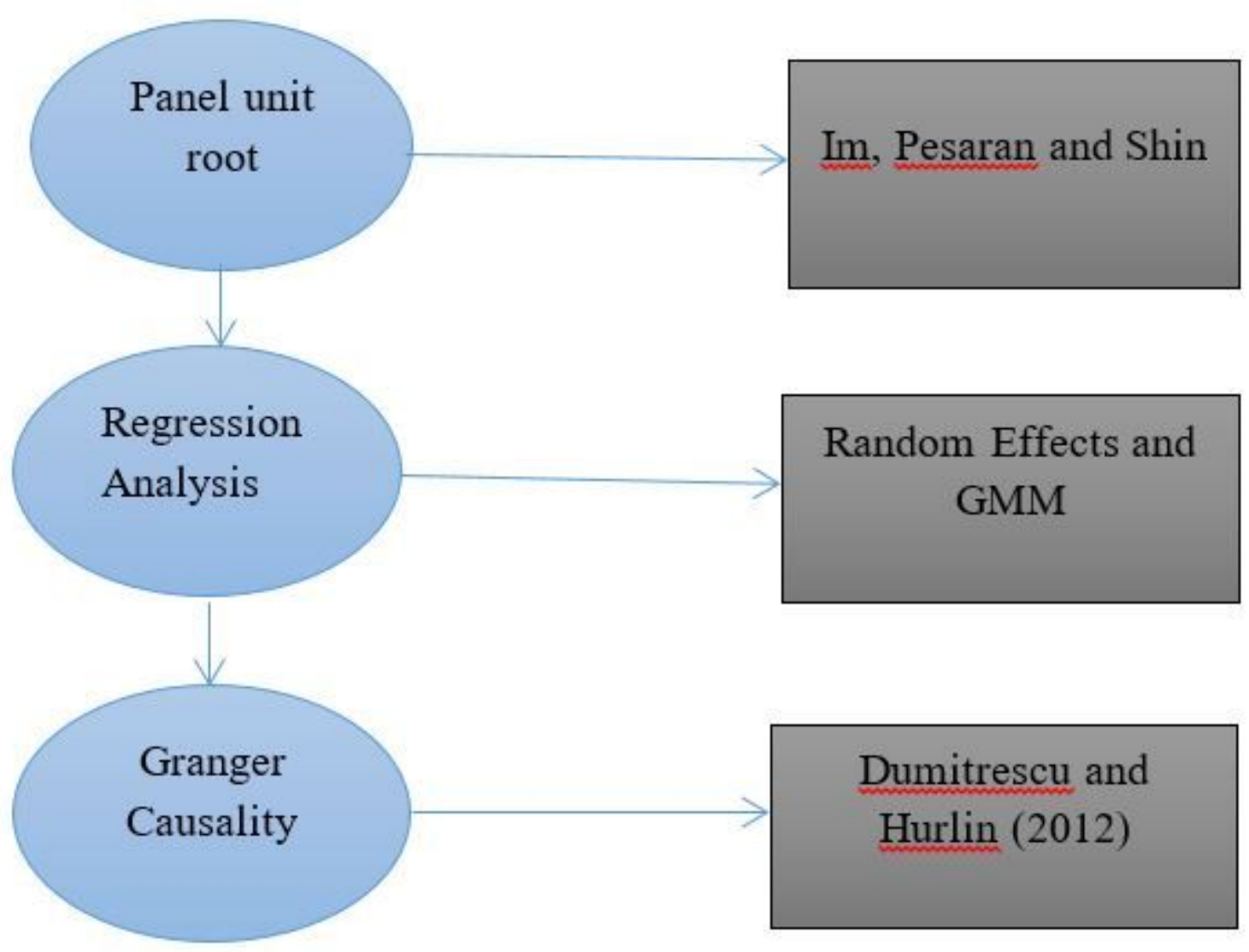

Figure 1

Analytical Framework

\section{Supplementary Files}

This is a list of supplementary files associated with this preprint. Click to download.

- Appendix.docx 